\title{
GREEK (CHRYSOSTOM) AND SYRIAC (EPHREM) ASPECTS OF "AUTHORITY" AS THE IMAGE OF GOD
}

\section{Introduction}

This topic has become prominent in current Patristic Studies due to the number of researchers, pursuing the problem of Greek-Syriac bilingualism. ${ }^{1}$ And it is of great importance to investigate the interaction of ideas which are contained in these languages themselves. This idea that can be found in the traditions which are often classed together as "Antiochene," can give the answer to the key question of Christian anthropology: What is the image of God in human beings? "Antiochene" writers in both Greek and Syriac give the same answer to the problem of the imago Dei: it is "authority." It would be quite difficult to discover the origin of this idea, but at least we can suppose that it was based on a literal exegesis of Gen. 1:26-28. It means that the verses "Let us create man in our image and likeness," and "have dominion over the fish of the sea and over the birds of the air and over the cattle and over the whole earth and over every crawling living thing that crawls upon the earth," were closely connected and the former was interpreted through the latter. One can find such an interpretation in the works of two of the most distinguished representatives of "Antiochene" Christianity: St. John Chrysostom and St. Ephrem the Syrian. Both of them are excellent examples showing Greek and Syriac aspects of the imago Dei concept, since they are well-known for a perfect command of their native languages. Chrysostom was a genius of Attic Greek, a brilliant rhetorician, philosopher, and theologian and Ephrem was the greatest poet of the patristic age and the most famous Syriac theologian. Both of them considered the image of God in humans as being "authority." However, they understood the idea in different ways because of lan-

(1) For example, see S. BRock, From Ephrem to Romanos: Interactions between Syriac and Greek in Late Antiquity (Aldershot, 1999); R. B TER HAAR RoMENy, A Syrian in Greek Dress. The Use of Greek, Hebrew, and Syriac Biblical Texts in Eusebius of Emesa's Commentary on Genesis (Leuven, 1997). 
guage differences: Ephrem named it xُطْ (shultana) and Chrysostom called it $\dot{\alpha} \varrho \chi \eta$.

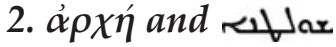

First of all, the original meanings of both terms should be reconstructed. Since the background of the "Antiochene" concept of the imago Dei is Semitic, the Syriac vor ought to be analysed first. The way it is used in the theology and philosophy of St. Ephrem was thoroughly investigated by Robert Murray, S.J. ${ }^{2}$ He argued that wor unites three ideas: 1) kingship; 2) free will, and 3) responsibility. Being such a complicated term, عمل lost some implicit meanings, when entering

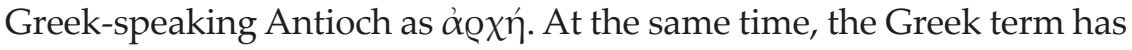
its own independent scope of meaning. The best approach for a philo-

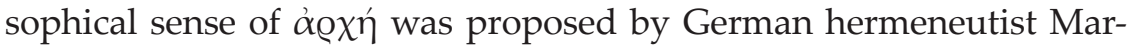

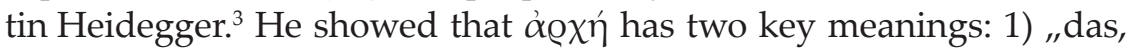
von woher etwas seinen Ausgang und Anfang nimmt;“ and 2) „das, was zugleich als dieser Ausgang und Anfang über das Andere, was von ihm ausgeht, weggreift und so es einbehält und damit beherrscht. ${ }^{* 4}$

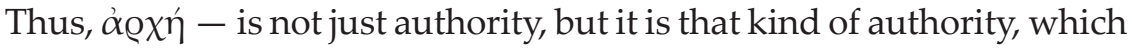

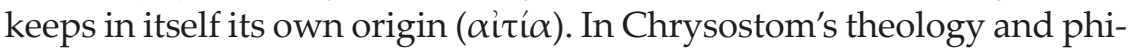

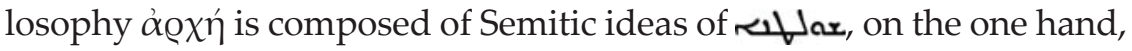
and its original sense in Greek philosophy, on the other. The origins of these semantic interactions can be discovered by means of a point-bypoint comparison of their spheres of usage, as follows.

\subsection{King of Animals}

In the world view of St. Ephrem or rather, an honorable position of God's viceroys, who were endowed with authority over the external world, especially over creatures. At the same time for Ephrem, free will and authority are both essential aspects of the imago Dei in humankind:

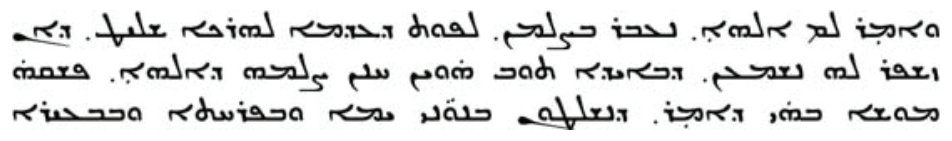

(2) R. Murray, S. J., The Ephremic Tradition and the Theology of the Environment, Hugoye 2.1 (1999); accessed at http://syrcom.cua.edu/Hugoye/Vol 2No1/HV2N1Murray.html on Dec. 21, 2007.

(3) M. Heidegger, Vom Wesen und Begriff der Physis, in: Idem, Wegmarken (Frankfurt am Main, 1967) 309-371.

(4) Heidegger, Vom Wesen und Begriff der Physis... 317. 


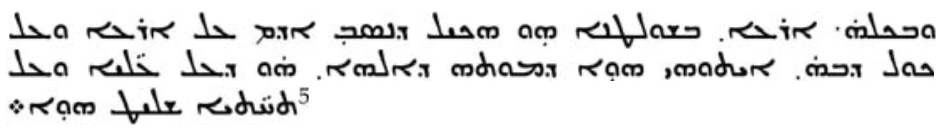

Thus human beings are considered to be custodians of the world since they were granted free will and are answerable to God for how it is treated. Chrysostom does not pay much attention to this topic, instead he claimed that $\alpha \varrho \chi \eta$ appears in possessing the external world,

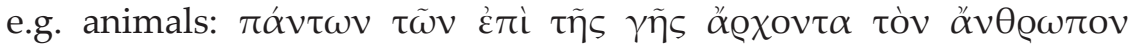

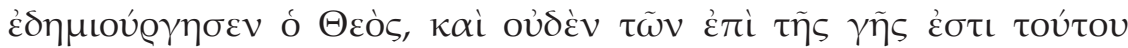

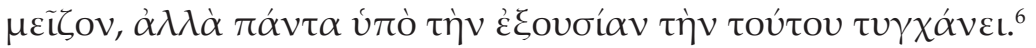

\subsection{Freewill and Self-Control}

At the same time Chrysostom maintained that $\alpha \varrho \chi \eta$ is a distinguishing feature of human beings, which appears in its structure as an ability to rule itself, or self-control. According to Chrysostom the soul is full of different thoughts $(\lambda \circ \gamma \iota \sigma \mu o i)$, which are of two kinds: some

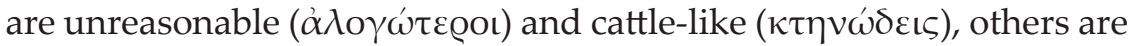

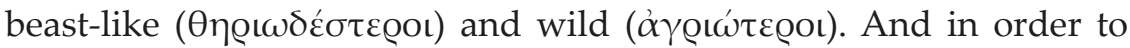
become like God in virtue, human beings need to $\alpha \dot{v} \tau \tilde{\omega} v$ кอ $\alpha \tau \varepsilon \tilde{\varepsilon} v \kappa \alpha i$

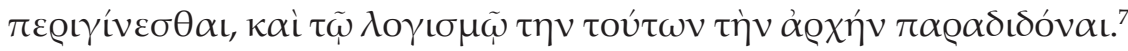
For Ephrem wax meant personal freedom to act rather than selfcontrol as long as free will is an implicit part of it:

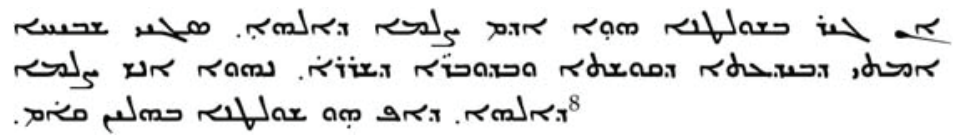

(5) "And God said: Let us make man in our image: that is to say, endowed with authority to the point that if it seems good to him he will obey us. Now what it means that we are in the image of God has been explained by Moses, where he says: and let them have authority over the fish of the sea and the birds, the cattle and all the earth. Thus it is in the authority (لva) that Adam received over the earth and all that is in it, that the likeness of God consists, to him who has authority over things above and below" (Ephrem, Hom. in Gen. 2.29 (CSCO 152, 23); tr. in Murray, The Ephremic Tradition..., pars. 6).

(6) "God created the human being as superior to all that exists on the earth and there is nothing over him, but everything under his power" (John Chrys., Hom. in Gen. 8; PG 53, 72).

(7) "...control and overpower them, giving authority over them to the mind" (John Chrys., Hom. in Gen. 3; PG 54, 591).

(8) "If it is by wax that Adam was the image of God, it is a most praiseworthy thing when a person, by knowledge of the truth and acting with truth, becomes the image of God, for that wax consists in these also (Ephrem, 
Anyhow in his works the image of kingship with a strong emphasis on the latter:

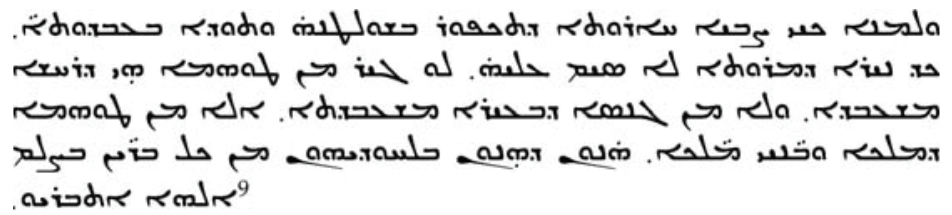

\subsection{The Proper Order of Things}

Further development of the anthropological program of Chrysostom appears in the claim that human beings are in countless relations

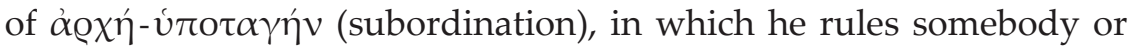

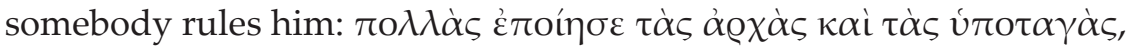

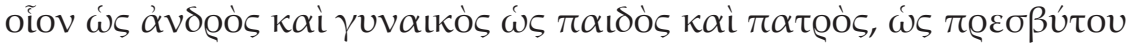

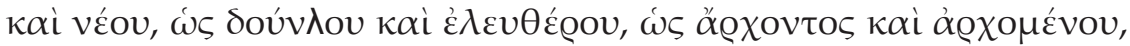

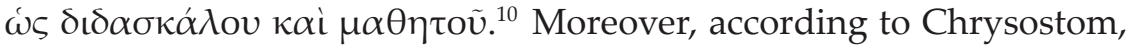

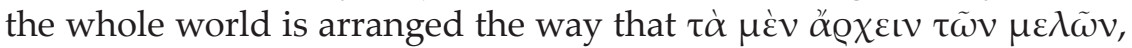

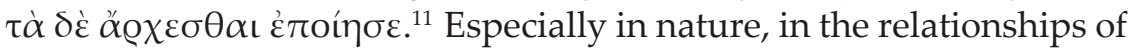
animals the proper order of things ( $\varepsilon \dot{v} \tau \alpha \xi \dot{\xi} \alpha)$ can be found, which is

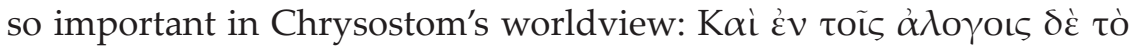

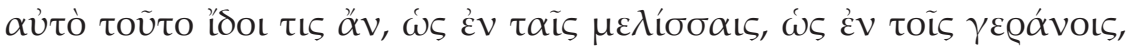

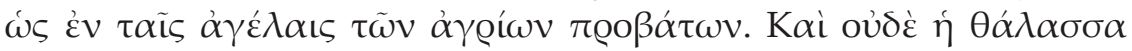

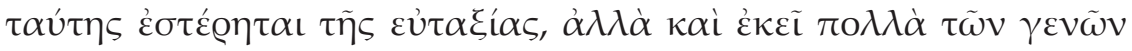

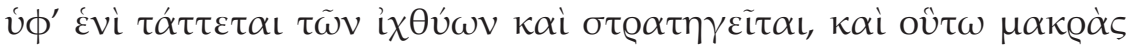

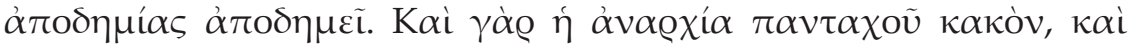

First Discourse to Hypatius, in: J. Overbeck (ed.), S. Ephraemi Syri... aliorumque opera selecta (Oxford, 1865) 22; tr. in C. W. Mitchell (ed.), Prose Refutations, I (London 1912), 3. Following Murray's adaptation, 2 لیx was left untranslated. But Mitchell renders it the first time by "Freewill," the second time by "independence."

(9) "And why does Freewill (בی⿱ to be enslaved when the yoke of kingship (- (-) is not placed upon it? For it is not of the race of enslaved reptiles, nor of the family of enslaved cattle, but of the race of a King and of the sons of Kings who alone among all creatures were created in the image of God" (Ephrem, First Discourse to Hypatius, 39; ed. Mitchell, Prose Refutations..., 14).

(10) "[God] has made many authorities and forms of subordination; such as, for instance, of man and wife, that of son and father, that of old men and young, that of slave and free, that of ruler and ruled, that of master and disciple" (John Chrys., Hom. in ep. ad Rom. 23; PG 60, 615); NPNF 1-11, 511).

(11) "Some of the limbs has [God] created to rule and some to be ruled" (John Chrys., Hom. in ep. ad Rom. 23; PG 60, 615); NPNF 1-11, 511-2. 


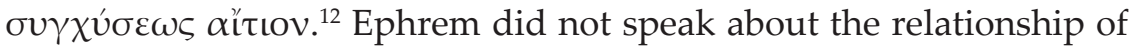
authority and subordination, but supposed a kind of network of mutual needs which binds humankind and all other creatures together:

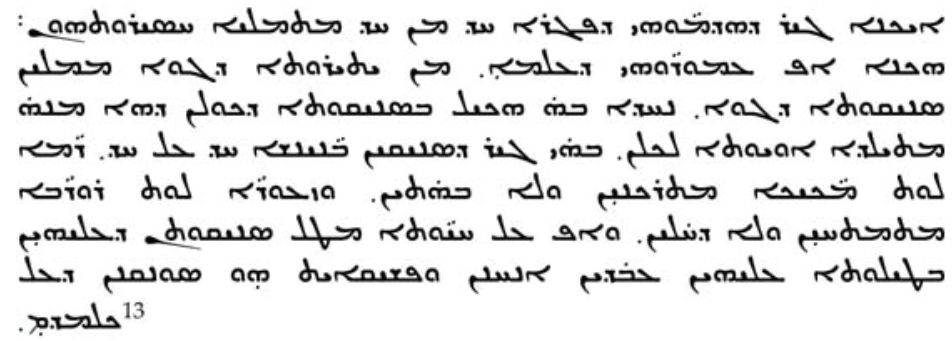

\subsection{The "Full Human"}

Chrysostom developed this concept in the ecclesiological and soteriological idea of the "full human," which does not belong to Ephrem in any respect. The head of the "full human" is God the Logos, Jesus Christ, and the body is the Church, or rather, oi $\pi \alpha v \tau \alpha \chi 0 \tilde{v} \tau \tilde{\eta} \varsigma$

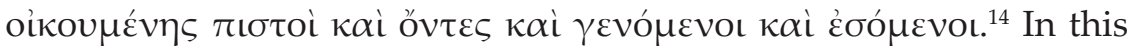

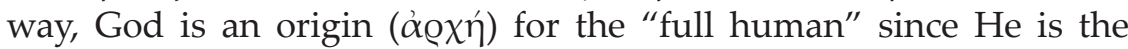
head, which rules over the whole body and its parts and gives them

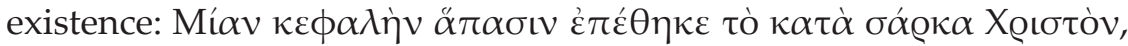

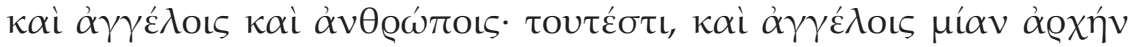

(12) "And among the unreasoning creatures one may notice this same principle, as amongst bees, amongst cranes, amongst herds of wild cattle. And even the sea itself is not without this goodly subordination; for there too many of the clans are ranged under one among the fishes, and are led thus as an army, and make long expeditions from home. For anarchy, be where it may, is an evil, and a cause of confusion" (John Chrys., Hom. in ep. ad Rom. 23; PG 60, 615); NPNF 1-11, 512.

(13) "For just as in the case of the limbs of the body, their individual needs are fulfilled by one another, so too the inhabitants of the world fill in the common need from the common excess. We should rejoice in this need on the part of us all, for out of it is born harmony (rhasar) for us all; for in that people need one another, those in high position stoop to the lowly and are not ashamed, and the insignificant reach out to the powerful and are not afraid. Even in the case of the animals, seeing that we have a need for them, we take care of them. Clearly our need for everything binds us with a love for everything" (Ephrem, First Discourse to Hypatius, 26; tr. in S. BRоск, The Luminous Eye: The Spiritual World Vision of Saint Ephrem the Syrian (Kalamazoo, 1992) 167).

(14) "The faithful throughout the whole world, those which are, and those which have been, and those which shall be" (John Chrys., Hom. in ep. ad Eph. 10; PG 62, 75); NPNF 1-13, 99. 


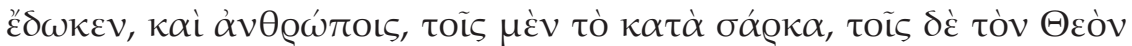
$\Lambda$ ó $\mathrm{ov}^{15}{ }^{15}$ This unity is similar to conjugal relations, where the husband is the head ( $\dot{Q} \propto \chi \eta)$ and wife is the body, ${ }^{16}$ while they are a united being with one image of God. Just as in the "full human" the head (Christ) is $\alpha \mathrm{Q} \chi \eta$ since He is the origin and initiator of everything in it, in the

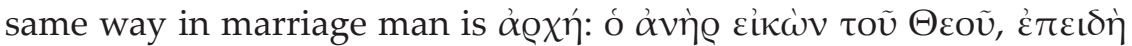

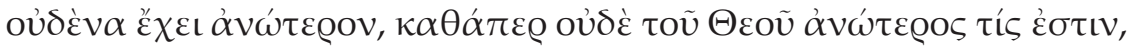

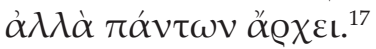

\section{Conclusions}

In this short article a first step has been made concerning the greater problem - a complete comparison of the origins of "Antiochene" anthropologies, including the Greek and Syriac traditions. The importance of this problem can hardly be overestimated: here lies the origin of controversies between these traditions and here also lies the key to solving it. It is easy to see that the free will concept, which was implicit in Ephrem's ogy. Thus free will was no longer connected with the image of God,

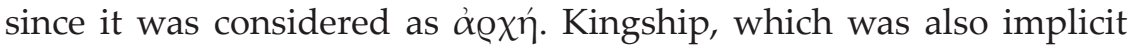
in ( was not important for the theological and philosophical approach of Chrysostom. When he thought of $\alpha \varrho x \eta$ he envisioned the notion of headship, but headship as an origin.

(15) "[God] has made many authorities and forms of subordination; such as, for instance, of man and wife, that of son and father, that of old men and young, that of slave and free, that of ruler and ruled, that of master and disciple" (John Chrys., Hom. in ep. ad Rom. 23; PG 60, 615); NPNF 1-11, 511).

(16) John Chrys., Hom. in ep. ad II Thes. 5; PG 62, 499-500.

(17) "Man is the image of God, since there is nobody over him, the same as there is no one above God, but he originates everything" (John Chrys., Hom. in Gen. 2; PG 54, 589). 


\section{SUMMARY}

In Patristic Studies the problem of Greek-Syriac bilingualism has currently become prominent, especially concerning the interaction of ideas, contained in these languages themselves, such as the concept of imago Dei. "Antiochene" writers in both Greek and Syriac consider the imago Dei in humans as being "authority." However St. John Chrysostom and St. Ephrem, outstanding "Antiochene" thinkers, understood the idea in different ways because of the language differences: Ephrem named it

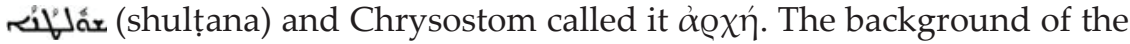
concept is Semitic and is presented in Syriac wax in the best way. But this term lost some implicit meanings, while entering Greek-speaking An-

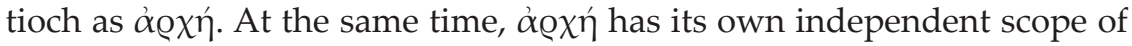
meaning. Thus, in Chrysostom's works $\alpha \varrho \chi \eta ́$ is composed of Semitic ideas and its original sense in Greek philosophy. 